\title{
The Effect of Fuel Variations Toward Honda CB 150R Performance
}

\author{
Hamid Nasrullah ${ }^{1, *}$ Bahtiar Wilantara $^{2}$ Parikhin $^{3}$ Fadil Jatmiko ${ }^{4}$ \\ 1,2,3,4 Department Automotive Engine, Politeknik Dharma Patria, Kebumen, Indonesia, 54311 \\ "Corresponding author.Email: hamid@politeknik-kebumen.ac.id
}

\begin{abstract}
The performance every mmotorcycles is influenced by several factors as usual, including the usage of fuel typed. The study aim was to determine the effect fuels such as pertalite, pertamax, and pertamax-turbo type toward the power performance, torque and exhaust emissions produced by a 4-stroke motorbike. The try-out test with experimental methods was done by using motorcylcle of Honda CB 150 R that produced in 2016 as a sample. A sportdyno V3.3 SD325 is a dynamometer used to measure a power and torque, meanwhile eshbon HG-510 is a gas analyzer to measure an exhaust emissions. The fuel variations are pertalite, pertamax, and pertamax turbo. The research finding of this study show that 4-point results, they are: 1) In the range 4,250 to 11,000 rpm showed the maximum pertalite power on 12.53 $\mathrm{kW}$ at $9,414 \mathrm{rpm}$, pertamax $12.48 \mathrm{~kW}$ at 9,265 rpm, pertamax-turbo $12.28 \mathrm{~kW}$ at 9,403 rpm. 2) In the maximum torque achieved by the pertamax-turbo is $14.07 \mathrm{Nm}$ at $7,237 \mathrm{rpm}$, pertalite $13.88 \mathrm{Nm}$ at 7,300, and pertamax is 13.86 at 7,611 rpm. 3) In testing exhaust emissions placed on 1,500 to $7,500 \mathrm{rpm}$, pertalite fuel decreased $\mathrm{CO}$ from $2.92 \%$ to $0.61 \%$ and $\mathrm{HC}$ from $405 \mathrm{ppm}$ to $225 \mathrm{ppm}$, pertamax CO from $2.79 \%$ to $0.46 \%$ and $\mathrm{HC}$ from $393 \mathrm{ppm}$ to $170 \mathrm{ppm}$, and pertamax turbo $\mathrm{CO}$ from $2.44 \%$ to $0.38 \%$ and $\mathrm{HC}$ from $373 \mathrm{ppm}$ to $158 \mathrm{ppm}$. And the last, 4) the emission test takes into account the usage of high octane fuel will show the smaller impact on environmental pollution.
\end{abstract}

Keywords: Fuel Variations, Motorcycle Performance, Pertalite, Pertamax, Pertamax-Turbo.

\section{INTRODUCTION}

The combustion motorcycle itself requires some of factors such as fuel, air, and an ignition system are able to carry out the combustion process in the combustion chamber [1]. In general, the Indonesian vehycle, especially motorcycles, mostly, use pertalite, pertamax, and pertamax-turbo as the fuels [2]. The selection oon determining the fuel consumption as a fuels that appropriated with the type of specifications engine will influenced on the greatly affect the fuel consumptiontoward the vehicle performance [3]. Due to the fuel oil type has beeen appropriated, the maximum engine power can be achieved with just a little fuel spray [4].

The motorcycle power can be seen based on the power and torque numbers that generated by the motorbike [5]. The power and torque numbers can be determined by various measurement methods. One of methods to measure the power and torque of motorcycle is dyno test [6]. The power and torque measurement with dyno test can be done without dismantling the motorcycle engine, and it can help the technican to measure the engine easily with the vehicle wheels running on a roller that rotates on a dynamometer as a replacing tools [7]. In addition, another power and torque, the use of appropriate fuel will affect on the exhaust emissions result [8]. The method of measuring exhaust emissions toward a motorcycle can be done using a gas analyzer [9]. Then, it will be seen how much exhaust emissions itself are produced by these motorcycle [10]. Based on the description above, it is necessary to know about the use of the fuel tah appropriate for motorbikes, especially for Honda CB 150 R motorbikes. In this study, the research will conduct on the use of pertalite, pertamax, and pertamax-turbo fuels to examine the power, torque, and emissions exhaust gas produced [11]. In short, it will be known how the effect on using Pertalite, Pertamax, and Pertamax-turbo fuels toward the performance of gasoline engines on the Honda CB 150 R [12].

\section{METHOD}

The several methods were used to obtain data, to discussion, and to know the materials needed in order solve research problems are as follows: 


\subsection{Literature Reviews}

The literature study method is a technique that is carried out by looking for information related to fuel and the combustion system on a motorcycle as a reference [13].

\subsection{Documentation Method}

The activities carried out in the documentation method are collecting information, information, and evidence during the dyno test at the Mototech Yogyakarta workshop [14].

\subsection{Experimental Method}

An experimental method is a method used to analyze power, torque, and exhaust gas emissions by pertalite, pertamax, and Pertamax turbo [15].

\section{RESULT AND DISCUSSION}

\subsection{Results}

According to the tryout test results based on the motorcycle performance with fuel variations pertalite, pertamax and pertamax turbo, it can be compared that each character of power $(\mathrm{P})$, torque $(\mathrm{T})$ in one graph, and Exhaust Gas Emissions [16].

\subsubsection{Power}

The power produced by the three types of fuel can be compared in the form of a graphic can be seen clearly in the Figure 1 .

\subsubsection{Torque}

For the torque tryout test with the fuel variations pertalite, Pertamax, and Pertamax turbo, it can be compared in the form of a graph presented in Figure 2 as follows[17].

\subsubsection{Exhaust Gas Emissions}

The tryout testing exhaust emissions in the form of carbon monoxide (CO) in pertalite, pertamax, and pertamax turbo fuels are presented in Figure 3 as follows [2]. The tyout testing exhaust emissions result in the form of hydrocarbon (HC) in pertalite, pertamax, and pertamax turbo fuels are presented in Figure 4.

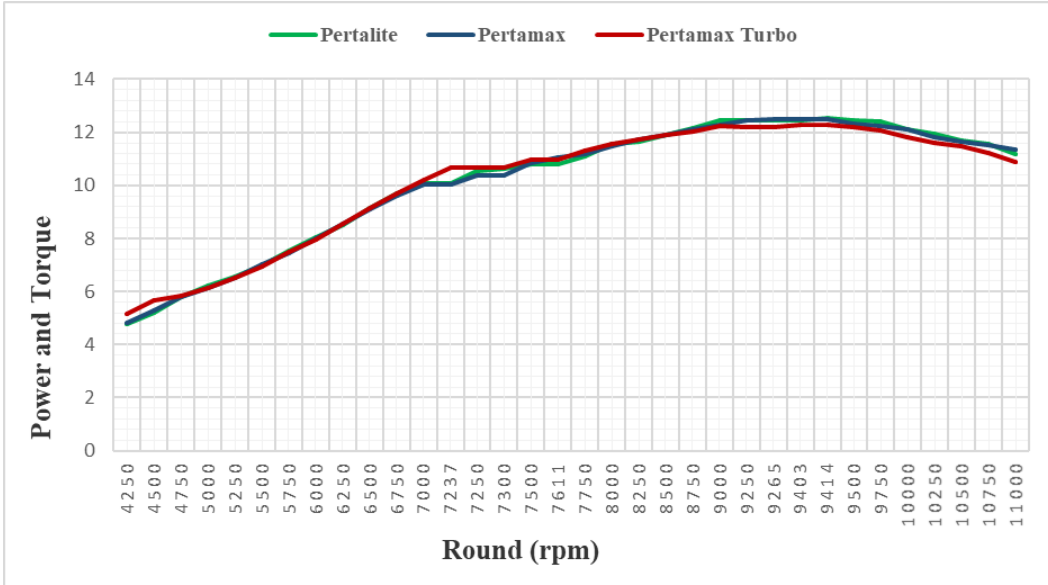

Figure 1 Engine power comparison on fuel variations

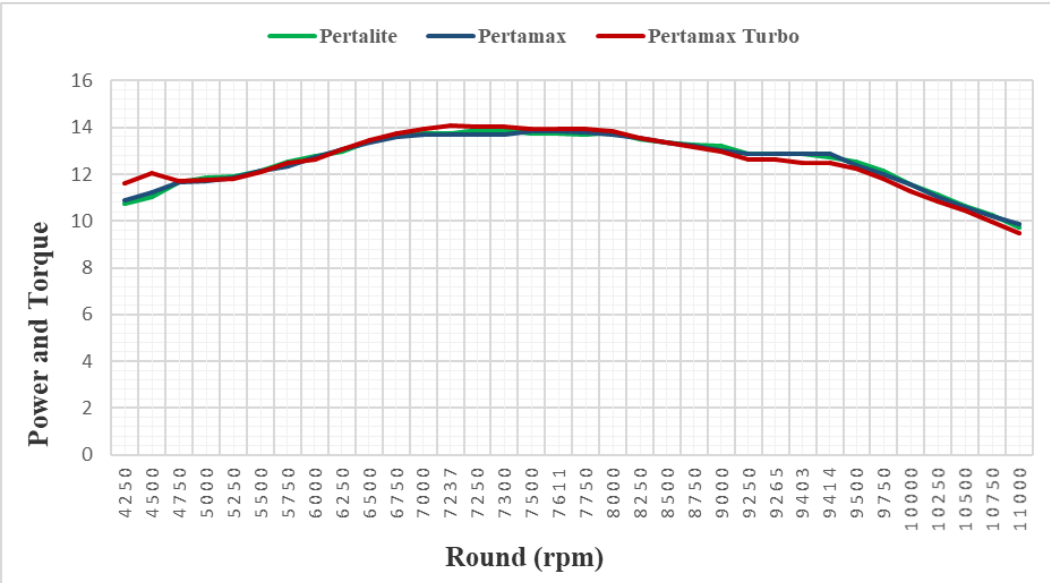

Figure 2 Engine torque comparison on fuel variations 


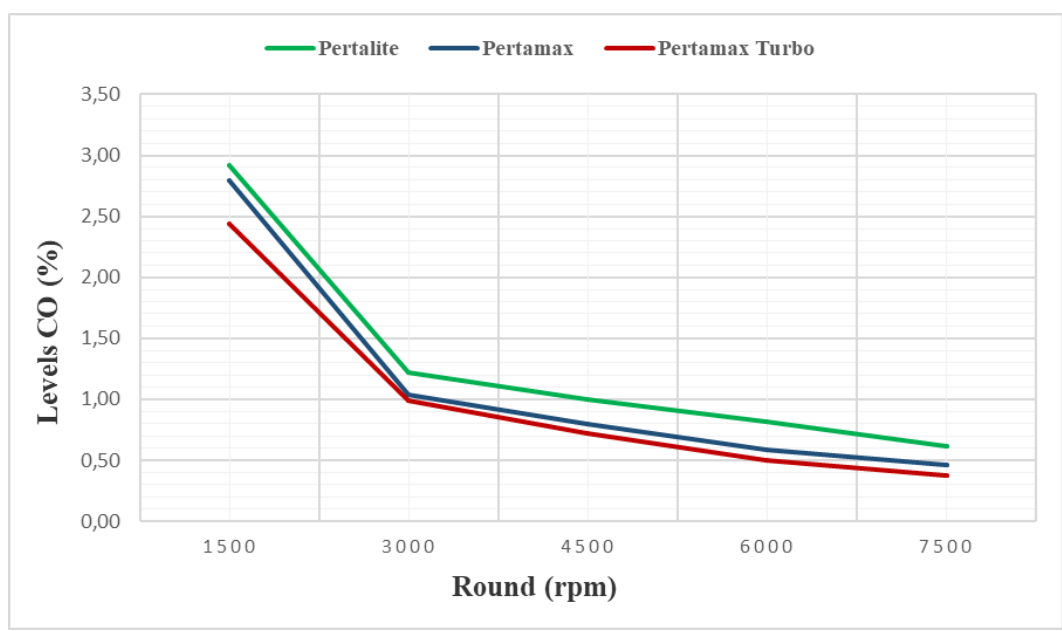

Figure 3 Comparison carbon monoxide on various fuels

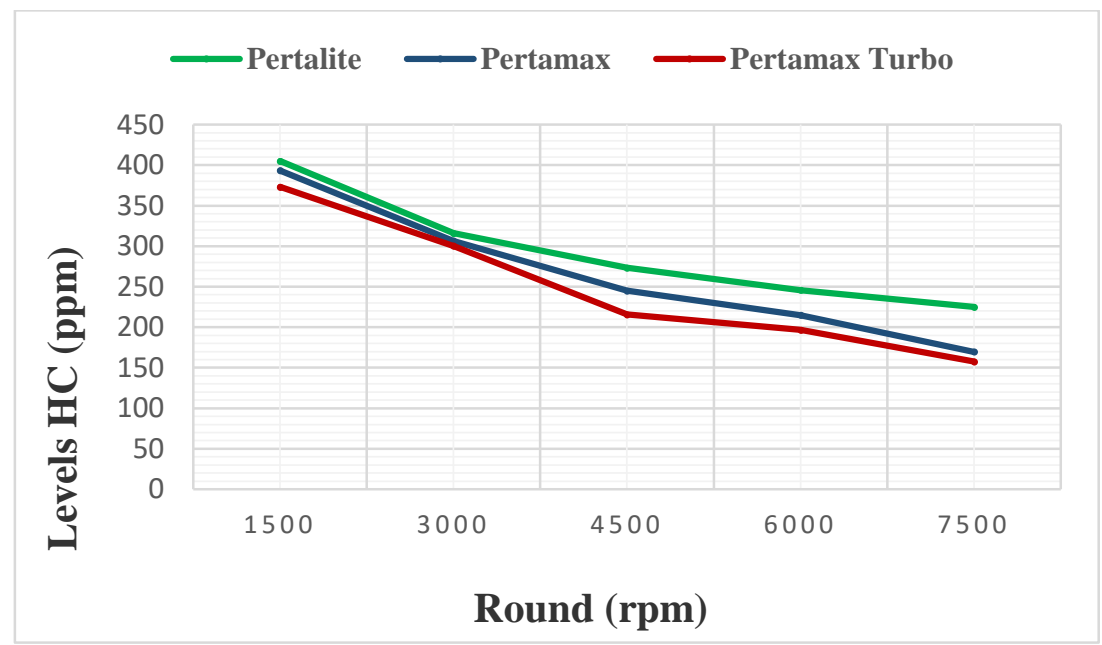

Figure 4 Hydrocarbon Comparison chart on a variety of fuels

\subsection{Discussion}

\subsubsection{Power}

Based on the power graph in Figure 1, it can be seen that the highest power is achieved by pertalite fuel on $12.53 \mathrm{~kW}$ at $9,414 \mathrm{rpm}$. The second place is placed by Pertamax fuel with $12.48 \mathrm{~kW}$ at 9,265 rpm. Then, the last is Pertamax turbo fuel on $12.28 \mathrm{~kW}$ at $9,403 \mathrm{rpm}$. Power is affected by the value of torque and rotation. The decrease in power is slower than the decrease in torque due to the increase in the value of rotation is still higher than the decrease in the value of torque [18]. So, even though the torque has decreased, the power still rises before finally it is decreasing according to the torque.

\subsubsection{Torque}

In figure 2, when the gas handle is increased the torque increases sharply from 4,250 rpm to around 4,500 $\mathrm{rpm}$, due to to there is an increase in fuel consumption into the cylinder. After rotating at around $8,000 \mathrm{rpm}$ the torque begins to decrease due to a decrease in the average effective pressure or break mean effective pressure (bmep) due to the high frequency of piston speed, but it is not balanced by the length of time the valve is open. So that there is a decrease in fuel combustion pressure in the cylinder [19]. In the torque graph above, the maximum torque produced by Pertamax turbo fuel is higher than the other two types of fuel, which is 14.07 at $7,237 \mathrm{rpm}$. Followed by pertalite fuel with a torque of 13.88 at 7,300 rpm and Pertamax fuel with a torque of 13.88 at 7,611 rpm.

\subsubsection{Exhaust Gas Emissions}

In the exhaust emission test presented in Figure 3, for carbon monoxide (CO) using pertalite fuel, it decreased on $0.61 \%$ and still on below the standard at $4.50 \%$. Pertamax fuel has decreased on $0.46 \%$ and still on below the standard at $4.50 \%$. Meanwhile, Pertamax turbo fuel has decreased on $0.38 \%$ and still on below the standard at $4.50 \%$.

In the exhaust emission tryout test presented in Figure 4 showed that for hydrocarbons (HC) using pertalite fuel, it has decreased on $225 \mathrm{ppm}$ and still on below standard 
at the 2,000 ppm. Pertamax fuel has decreased to 170 ppm and still on the below standard at 2,000 ppm. While, in the Pertamax turbo fuel has decreased on $158 \mathrm{ppm}$ and still on the below standard at 2,000 ppm.

\section{CONCLUSION}

Based on the research has been conducted, in short, it can be caonclude in three points that can be read as follows:

a. The tryout test results show that pertalite is better than Pertamax and Pertamax turbo in terms of power. It is indicated by pertalite fuel producing a maximum power of $12.53 \mathrm{~kW}$, followed by Pertamax which is on $12.48 \mathrm{~kW}$, and Pertamax turbo which is on 12.28 $\mathrm{kW}$.

b. The tryout-test results show that the Pertamax turbo is better than Pertalite and Pertamax in terms of torque. It is indicated by the fuel Pertamax produces a maximum torque of $14.07 \mathrm{Nm}$, followed by pertalite which is on $13.88 \mathrm{Nm}$ and Pertamax is on $13.86 \mathrm{Nm}$.

c. The results of the exhaust emission tryout test showed on 1,500 rpm, 4,500 rpm, 7,500 rpm. In additon, CO and $\mathrm{HC}$ have decreased. It can be seen on the Pertalite fuel on decrease in CO from $2.92 \%$ to $0.61 \%$ and $\mathrm{HC}$ on $405 \mathrm{ppm}$ to $225 \mathrm{ppm}$. Pertamax fuel has decreased CO from $2.79 \%$ to 0.46 and HC 393 ppm to $170 \mathrm{ppm}$. Pertamax turbo fuel has decreased CO from $2.44 \%$ to $0.38 \%$ and $\mathrm{HC}$ on $373 \mathrm{ppm}$ to $158 \mathrm{ppm}$.

\section{ACKNOWLEDGMENT}

The authors would like to express his deepest gratitude to Polytechnic Dharma Patria Kebumen, and the students who always help, support and facilitate in completing this research well. Hopefully, the research result can be useful as references for the readers, academicion, enginers, technicans, and Indonesian society in general.

\section{REFERENCES}

[1] U. Of, B. As, A. Fuels, O. Machine, G. Set, and M. Equipment, "Automotive engineering education journals," pp. 1-7, 2018.

[2] R. R. Rusdiani and R. Boedisantoso, "Emission Factors from $\mathrm{HC}, \mathrm{CO}$, and CO 2 of Pertalite and Pertamax Fueled Motorcycle in Surabaya City , Indonesia," vol. 5, no. 7, pp. 96-100, 2018.

[3] E. Julianto, D. Stiawan, and E. Sarwono, "Effect of Ignition System in Motorcycle To Performance and Exhaust Gas Emissions With Fuel Ron," vol. 14, no. 2, pp. 88-93, 2020, doi: 10.24853/sintek.14.2.7479.
[4] S. Suyitno, "Automotive Experiences," Automot. Exp., vol. 2, no. 2, pp. 41-46, 2019.

[5] V. N. Duy, K. N. Duc, D. N. Cong, H. N. Xa, and T. Le Anh, "Experimental study on improving performance and emission characteristics of used motorcycle fueled with ethanol by exhaust gas heating transfer system," Energy Sustain. Dev., vol. 51, pp. 56-62, 2019, doi: 10.1016/j.esd.2019.05.006.

[6] A. Hassani and V. Hosseini, "An assessment of gasoline motorcycle emissions performance and understanding their contribution to Tehran air pollution," Transp. Res. Part D Transp. Environ., vol. 47, no. October 2002, pp. 1-12, 2016, doi: 10.1016/j.trd.2016.05.003.

[7] Maridjo, I. Yuliyanti, and R. Angga, "Pengaruh Pemakaian Bahan Bakar Premium , Pertalite Dan Pertamax Terhadap Kinerja Motor 4 Tak,' Pengaruh pemakaian bahan bakar premium, pertlite dan pertamax terhadap kinerja Mot. 4 Tak, vol. 9, no. November, pp. 73-78, 2019.

[8] I. W. B. Ariawan, I. G. B. Kusuma, and I. W. B. Adnyana, "Pengaruh Penggunaan Bahan Bakar Pertalite Terhadap Unjuk Kerja Daya, Torsi, Dan Konsumsi Bahan Bakar Pada Sepeda Motor Bertransmisi Otomatis," J. METTEK, vol. 2, no. 1, pp. 51-58, 2016.

[9] L. O. I. Syahrullah and N. Sinaga, "Optimization and prediction of motorcycle injection system performance with feed-forward back-propagation method Artificial Neural Network (ANN)," Am. J. Eng. Appl. Sci., vol. 9, no. 2, pp. 222-235, 2016, doi: 10.3844/ajeassp.2016.222.235.

[10] C. Arcoumanis, C. Bae, R. Crookes, and E. Kinoshita, "The potential of di-methyl ether (DME) as an alternative fuel for compression-ignition engines: A review," Fuel, vol. 87, no. 7, pp. 10141030, 2008, doi: 10.1016/j.fuel.2007.06.007.

[11] K. Hou, B. Deng, Y. Chen, J. Ran, and J. Fu, "For cleaner exhaust of a high performance motorcycle: A macroscopic comparative study of catalytic converters under world-wide motorcycle test cycle," J. Clean. Prod., vol. 284, p. 124730, 2021 , doi: https://doi.org/10.1016/j.jclepro.2020.124730.

[12] J.-H. Tsai, P.-H. Huang, and H.-L. Chiang, "Characteristics of volatile organic compounds from motorcycle exhaust emission during realworld driving," Atmos. Environ., vol. 99, pp. 215 226 , 2014 , doi: https://doi.org/10.1016/j.atmosenv.2014.09.076. 
[13] A. Habibie and W. Sutopo, "A Literature Review: Commercialization Study of Electric Motorcycle Conversion in Indonesia," IOP Conf. Ser. Mater. Sci. Eng., vol. 943, p. 012048, 2020, doi: 10.1088/1757-899x/943/1/012048.

[14] H. Nasrullah and R. Saputra, "Rancang Bangun Fuel Pump Pressure Tester," vol. 3, no. 1, pp. 1321, 2018.

[15] M. T. Muslim, H. Selamat, A. J. Alimin, N. Mohd Rohi, and M. F. Hushim, "A review on retrofit fuel injection technology for small carburetted motorcycle engines towards lower fuel consumption and cleaner exhaust emission," Renew. Sustain. Energy Rev., vol. 35, pp. 279-284, 2014 , doi: https://doi.org/10.1016/j.rser.2014.04.037.

[16] H. Maksum, "Perbandingan Penggunaan Berbagai Jenis Bahan Bakar Terhadap Emisi Gas Buang Pada
Sepeda Motor 4 Langkah," Jur. Tek. Otomotif FT UNP, vol. 8, no. 1, pp. 1-9, 2017.

[17] I. Wayan Sugita, D. Rio Budi Syaka, and A. Irianto Wahyudi, "Effect of Pertalite - Methanol Blends on Performance and Exhaust Emission of a Four-stroke 125 CC Motorcycle Engine," KnE Soc. Sci., vol. 3, no. 12 , p. 384,2019 , doi: 10.18502/kss.v3i12.4105.

[18] L. Li et al., "Effect of gasoline/methanol blends on motorcycle emissions: Exhaust and evaporative emissions," Atmos. Environ., vol. 102, pp. 79-85, 2015 , doi: https://doi.org/10.1016/j.atmosenv.2014.11.044.

[19] A. M. Siregar, C. A. Siregar, and M. Yani, "Engineering of motorcycle exhaust gases to reduce air pollution," IOP Conf. Ser. Mater. Sci. Eng., vol. 821, no. 1, 2020, doi: 10.1088/1757899X/821/1/012048. 